Criação / Conto 


\section{Uma anedota de velório}

\section{AUTRANDOURADO}

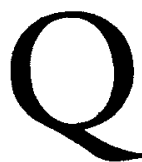

UEM NASCEU E SEMPRE morou em cidade grande, onde o ritual da morte é higiênico, frio e automatizado, com suas capelas mortuárias confortáveis e seus ritos modernos, coroas de flores como enormes salva-vidas, não pode imaginar a morte e sua parafernália numa pequena cidade do interior mineiro como era Duas Pontes. Queremos nos referir à festa em que muitas vezes se transformava o velório lá pelas tantas da noite, quando as famílias de bem se retiravam e só permaneciam os veloristas contumazes, os amantes da sublime arte da conversação vadia. $\mathrm{Na}$ verdade, o velório, pela altura da meia-noite, tirante uma ou outra lágrima ou suspiro retardatários, era uma verdadeira festança. Daí a razáo do convite às pessoas amigas da casa ou do falecido. Não que estranhos ao finado ou à família não comparecessem, mas não eram bem-vistos pelos familiares e pelos verdadeiros amigos do morto, os convidados formais. Em velório de mulher a coisa era mais comedida, se guardava um certo recato; velório de homem é que costumava virar festa rasgada, muitas vezes sem nenhum comedimento. Nunca se teve notícia de velório com dança, mas com música sim, no passamento do Chico da Lalinha, como se verá.

Quando soava a última pancada do relógio anunciando a meia-noite, começavam a servir vinho, café ou a boa e gostosa cachaça, forte e seca, tirada do alto do alambique. Como cachaça de barriga vazia não faz bem ao estômago e leva ligeiro à embriaguez, se servia o competente tira-gosto, o forra-bucho de muita proteína, como torresmo, pele de porco bem sequinha, crocante, pedaços de lingüiça e mesmo costeletas de porco.

No capítulo do restilo acompanhado dos derivados de porco, os velórios de gente remediada eram os melhores. Os velórios de gente rica não tinham muita graça, apesar de que o passadio era melhor; havia, vamos dizer, algum recato. Nas classes baixas, de defunto pobre, a coisa engrossava logo por causa do excesso de bebida sem o complemento de proteína, às vezes degringolando em brigas nas quais a faca furava muita barriga; se matava gente que no dia seguinte seria objeto de novo velório, quer dizer - de nova farra.

Dois velórios ficaram famosos. O primeiro foi o velório do major Bernardino do Amaral. A certa altura, não se sabe como, surpreenderam o conquistador e desencaminhador de donzelas Fábio Proença, com seu bigodinho cinematográfico, voz baixa ciciante, encoxando dona Natália de Sousa Amaral, até então tida e 
havida como senhora de respeito. Ser dadivosa era o de menos, algumas mulheres da cidade eram, sabia-se, falavam. O pior da história é que ela era viúva de defunto fresco, de corpo presente. Na noite do velório do marido abrir as pernas para um pilantra como Fábio, cujo apelido diz bem o que ele era - Fabinho Bom de Bico! Até diziam dele os que lhe prognosticavam um fim trágico: se bico valesse, tucano era advogado.

Diante do vexame, sem dizer nada, sem nem mesmo se despedirem da família e da impudica viúva (agora recomposta no seu solene vestido preto, a cara coberta de véu), todos foram saindo de fininho. Para não perder a caminhada, diziam uns; por castigo, diziam outros, o certo é que pilharam a copa e a cozinha do major e foram fazer a maior farra no Largo do Carmo.

Caso de notável velório foi o do boêmio, violeiro e emérito cantor de seresta, Francisco de Menezes Albuquerque, o Chico da Lalinha, por ser filho de nossa querida Lalinha, viúva do coronel Antônio Gomes de Albuquerque. Viúva de coronel era indicativo de que ela pertencia às grandes famílias endinheiradas de Duas Pontes. Quando o marido morreu, ela fazia parte da alta burguesia da cidade, mas o tempo foi passando, o filho não querendo saber nada de trabalho, a fortuna do coronel se esvaiu e eles eram agora (eles quer dizer: a mãe, Francisco, Rosália e Cremilda, duas solteironas) apenas remediados, vivendo de umas terras alugadas e de juros de apólices do governo.

Tudo ia muito bem no velório até precisamente meia-noite e meia, quando Gabriel Soares, outro cantor de seresta, viu num canto da sala o violão de Chico da Lalinha e resolveu, a princípio dedilhando apenas, para depois começar a cantar, esquecido do defunto ou em sua homenagem, não se sabe, com sua voz possante, os versos dolentes e doloridamente românticos da modinha Elvira, escuta. E todos o seguiram nos versos: "Elvira, escuta os meus gemidos,/ Que aos teus ouvidos/Irão chegar." Estava iniciada a memorável seresta.

Os amigos e companheiros de noites seresteiras de Chico da Lalinha foram buscar seus violóes, bandolins, violas, flautas e cavaquinhos, formando verdadeira orquestra, para cantar em homenagem ao amigo morto. E cantaram aquelas músicas todas de cortar o coração. $O$ restilo lubrificava as goelas secas e a cantoria não parava, varando a noite. A própria dona Lalinha veio se juntar ao coro e a uma pergunta que lhe fizeram ela disse estes versos são tão tristes como o meu coração. Depois, o Chico gostava demais dessas cantorias, é a maneira que temos de homenageá-lo.

E foram cantando a noite inteirinha e mesmo no saimento eles continuaram cantando atrás do caixão, e até os que seguravam as alças, sérios e solenes, o que fez com que se juntasse gente de todo lado por onde passava o cortejo fúne- 
bre, transformando o enterro do remediado Chico da Lalinha no maior enterro da nossa cidade, maior e mais imponente do que o do coronel Sigismundo Aroeira, o chefe político da cidade. Nunca se vira enterro igual ao de Chico da Lalinha. Quem estava na janela ou no passeio vinha se juntar ao imenso coro, era como se toda a cidade chorasse em música o seu cantor.

Quem podia contar essas e as melhores histórias de velório era o velho capitalista Baltasar de Oliveira. Se chamava capitalista naquelas eras quem não fazia absolutamente nada e vivia de rendas, em geral de dinheiro emprestado a juros de usura.

Poucas vezes seu Baltasar deixou de ser convidado para velório. Mesmo quem não era amigo dele, sabendo de sua paixáo por velório, o convidava se perdia um parente. Não apenas por solidariedade, mas por ser ele muito útil naquelas ocasióes, quando a família se perdia no desespero e alguém tinha de tomar providências objetivas e práticas.

Na verdade ele sabia tudo de defunto. Não que fosse necrófilo, ao contrário: tinha horror à cor cerúlea das mãos cruzadas sobre o peito, um terço entre os dedos, o lenço segurando o queixo, os tufos de algodáo tapando as narinas do morto. Apenas ao chegar dava uma olhadela protocolar, à distância, as suas narinas eram muito sensíveis a cheiro rançoso de defunto, por mais que mil flores procurassem abafar o fedor à medida que as horas iam se passando e $o$ corpo apodrecendo.

Seu Baltasar ficava sentado num canto e contava, sem se cansar, a cada um que chegava, como tinham sido os últimos momentos de agonia do falecido, que era a primeira coisa que ele procurava saber quando chegava num velório. Das mortes, as suas preferidas eram as de longas agonias; não gostava nada das mortes súbitas, no meio da noite, em pleno sono. Nestes casos, depois de narrar brevemente como pedia a morte repentina, ele dizia morreu feito um passarinho.

Quando alguém da família ia encomendar o caixão, ele ia junto. Uma vez que ele não foi, houve um verdadeiro desastre. Deram a medida do falecido pela sua carteira de reservista e o carapina não se lembrou que o homem quando esfria cresce exatamente sete centímetros. Onde é que seu Baltasar tinha haurido essa ciência, nunca se soube. Os próprios médicos ficaram surpreendidos quando souberam.

No caso do desastre tiveram de ir acordar o carapina Seitinni, para ele dar um jeito, as pernas do falecido não cabiam no caixão. Devido já ser muito tarde e não ter o carapina tempo para fazer outro caixão, a única maneira que ele encontrou para resolver o problema foi serrar a parte de baixo, onde deviam apoiar os 
pés. Cobriram então os pés e as canelas do fạlecido (seria, mesmo sem o aumento creditado à morte, um defunto enorme) com véus e flores que não conseguiam disfarçar o serviço mal feito. De pouco valia o disfarce, era o que mais se comentava no velório, não é todo dia que tem um caso assim.

Pois foi exatamente a uma figura tão útil e preciosa como era Baltasar de Oliveira que Nico deixou de convidar para o velório do pai dele. Baltasar se sentiu ofendido por várias razóes, sendo a principal delas o ressentimento. $O$ pai de Nico era um velho fazendeiro rico, e a riqueza alheia sempre incomoda.

O nosso herói (se é que se pode chamá-lo de herói, é capaz de que sim, tão diferente, sorumbático e estranho ele era) costumava ficar depois da janta, até a hora de se recolher ao leito, na janela da casa. Era a sua gávea ou vigia, de onde ele tinha notícia de tudo que se passara, estava ou iria certamente se passar na pequena Duas Pontes. Como a janela do quarto era baixa, de tanto ficar com os cotovelos apoiados no parapeito, ele os tinha calejados e os pijamas puídos, pijamas que vestia desde que se recolhia ao quarto depois da janta, quando lia o jornal paulista de que era assinante e que chegava no expresso das cinco da tarde.

Quando acabava a leitura minuciosa do jornal e a noite caía (ele era viúvo), para não gastar luz ficava no escuro à espera de seus informantes. Como esperado, o principal assunto era quem estava em agonia ou quem tinha morrido de repente, para cujo velório seu Baltasar seria necessariamente convidado. Então ele se vestia solenemente no seu melhor parelho preto e lá ia fruir o seu prazer, solidariedade ou distração, é difícil saber ao certo.

Um dos seus melhores e mais pontuais informantes era seu Belo, o farmacêutico. Muito religioso, ele ia toda noite, de volta da reza, dar o seu passeio no Jardim de Cima, e na volta passava pela gávea de seu Baltasar, de onde este avistava as ondas e as velas do seu pequeno mar. Como ele conversasse com muita gente, o mesmo acontecia com seu Belo na farmácia, necessário ponto de encontro e conversação.

Seu Baltasar achou muito estranho seu Belo não passar uma noite por sua janela, quando havia velório era normal os dois serem convidados: seu Belo por ser farmacêutico, que aviava as últimas receitas do falecido, seu Baltasar por seu trato e conhecimento de defunto. Cuidou até em mandar saber na casa do amigo o que tinha acontecido, qual o motivo daquela inusitada ausência. Se conteve: para sermos mais precisos, a filha é que não deixou ele mandar saber. Seu Baltasar acabou resolvendo se conformar.

Seu Belo não estava doente. No dia seguinte, na hora do costume (se seu Baltasar se importasse com o tempo cronológico, poderia acertar o relógio pela chegada do amigo, pontual e medido) ele parava diante da janela de seu Baltasar. 
Você não apareceu ontem, Belo, disse seu Baltasar. Quê que houve? Não vim porque fui no velório do coronel Abdias, pai do Nico, disse seu Belo. O pai do Nico morreu? disse seu Baltasar surpreso e revoltado. Morreu, a esta hora os vermes já devem estar empanturrados, disse seu Belo. Tinha cachaça? disse seu Baltasar. Tinha, da cabeça, de safra particular, do alambique da fazenda deles, disse seu Belo. Sim senhor! disse seu Baltasar. Tinha torresmo! Tinha, disse seu Belo. Torresminho bem seco, da melhor qualidade. Tinha pele de porco? disse seu Baltasar. Igual poucas vezes eu tenho comido, disse seu Belo. Sequinha e quebrando com facilidade na primeira dentada. Tinha lingüiça? disse seu Baltasar. Tinha, disse seu Belo. E lombinho de porco? disse seu Baltasar. Tinha, disse seu Belo. Lombinho e costeleta. Deus é grande, ainda vai morrer um parente meu de lenta agonia e aqui que eu vou convidar o Nico! disse seu Baltasar fazendo o gesto obsceno.

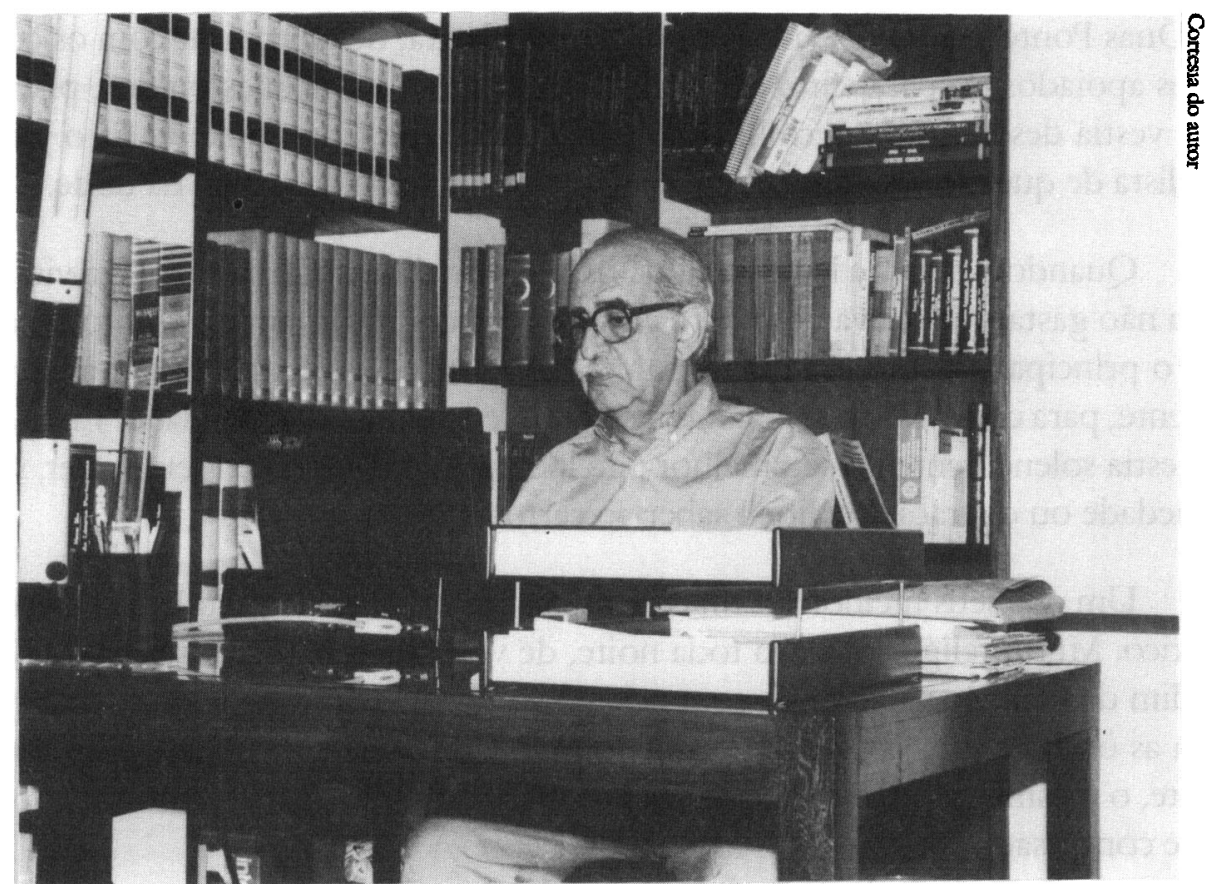

Autran Dourado, nascido em 1926 em Patos, Minas Gerais, começou seus primeiros estudos em Monte Santo, pequena cidade do mesmo Estado. Fez seu curso de Direito em Belo Horizonte, onde morou até 1954, quando se mudou para o Rio de Janeiro, a fim de ser secretário de imprensa do presidente Juscelino Kubitschek. Dessa vivência política nasceu o romance $A$ serviço del'Rei.Em 1981, o escritor recebeu do governo alemão o prêmio Goethe de Literatura por seu livro de contos As imaginafóes pecaminosas. Seus livros estáo traduzidos em diferentes idiomas e o romance $O s$ sinos da agonia foi adotado para os exames de agregaçáo das universidades francesas. A Unesco escolheu o romance $O$ pera dos mortos para fazer parte de sua coleção de obras representativas da Literatura Universal. 